Annals of Warsaw University of Life Sciences - SGGW

Land Reclamation No 49 (2), 2017: 117-127

(Ann. Warsaw Univ. of Life Sci. - SGGW, Land Reclam. 49 (2), 2017)

\title{
Studies on resilient modulus value from cyclic loading tests for cohesive soil
}

WOJCIECH SAS, ANDRZEJ GŁUCHOWSKI, MACIEJ MITURSKI

Faculty of Civil and Environmental Engineering, Warsaw University of Life Sciences - SGGW

\begin{abstract}
Studies on resilient modulus value from cyclic loading tests for cohesive soil. In this article the cyclic CBR test as a reference method in determination of resilient modulus $\left(M_{r}\right)$ is confronted with results of cyclic triaxial and unconfined uniaxial cyclic test. The main idea of conducted experiments is establish relationship between cyclic loading tests in testing of natural subsoil and road materials. The article shows results of investigation on cohesive soil, namely sandy silty clay, commonly problematic soil in Poland. The results of repeated loading triaxial test resilient modulus were displayed in order to compare them with cyclic CBR test results by using the $M_{r}-\theta$ model. Some empirical correlation between factors obtained from triaxial test or uniaxial unconfined cyclic test and cyclic CBR test was introduced here. The behavior of resilient modulus was also examined in this paper.
\end{abstract}

Key words: cyclic, loading, cCBR, triaxial tests, resilient, modulus

\section{INTRODUCTION}

The problem of cyclic loads impact on soil structure is the subject of continuous research and consideration by scientists. In 1955, Hveem first noticed the resilient properties of granular materials (Sweere 1990). He noted that the resulting deformations under transient load are not permanent. The presented phenomenon describes the compressibility, which we call the capacity of the soil to reduce the volume under the applied load (Craig 2004). So far, the soil was characterized by the compressibility module $\left(M_{o}\right)$ expressed by the Pascal unit. As the expectations of road users grow, the ordering party demands higher and higher standards of ordered objects, while reducing costs. This has led to attempts to refine the design methods, which have led to the issue of cyclical loads and the accompanying effects.

In 1986, AASHTO guide first characterized the subgrade deformation properties by using a resilient modulus, a modification method that was published in 1993 to "The 1993 AASTHO Guide describes the following empirical design equation for flexible pavements" (Schwartz and Carvalho 2007).

The characteristic of the soil subjected to cyclical loads was defined by a resilient modulus of elasticity and denoted as $M_{r}$. Loads characterized by $M_{r}$ value refer to a low typically low frequency and fall within the range from 0.1 to $1 \mathrm{~Hz}$ (Peralta and Achmus 2010). Due to the low frequency in considerations the inertia forces can be omitted (Shajarati et al. 2012). The use of the new module is intended to distinguish spring behavior of the soil from the traditional properties of resilient materials that are defined by the Young's modulus 
$(E)$ and the Poisson's ratio $(v)$ (Araya 2011). The most reliable soil strength parameters can be obtained by using a triaxial compression apparatus. With this test you can determine such geotechnical parameters as the angle of friction, cohesion, Young's modulus. Studies are carried out on samples with a diameter $(D)$ around two times lower than its high $-H(H=2 D)$. Three test conditions can be distinguished in case of triaxial test. The unconsolidated undrained method (UU), the method is to quickly load the sample without pre-consolidation and without the ability to drain water during the load. Consolidated undrained (CU) method, The method is to load the sample after initial consolidation without the possibility of water draining. The consolidated drained method (CD) is carried out with preliminary consolidation and with the possibility of draining (Jastrzębska and Kalinowska-Pasieka 2015).

All test methods can be used to determine the resilient modulus, although different test conditions should be taken into account in the calculation. The resilient modulus is determined in a triaxial compression apparatus under cyclic loading conditions, which is standardized by AASHTO T-294-921:1994 and Eurocode PM-EN-13286-7:2004 (Sas et al. 2015). Among the available common research methods, the study in the triaxial compression apparatus most accurately reflects the behavior of the soil subgrade subjected to cyclical stress. However, it is possible and desired to determine the correlation coefficent between the triaxial compression test and other studies as for unconfined compressive strength. The accuracy of such correlation will be affected by the number of conducted tests. There is a need for such studies for economic reasons, unfortunately, triaxial compression testing is complex and time consuming. Costly equipment is required to carry them out, which is not able to conduct such studies in common road laboratory facilities. This problem leads to the inability to use the empirical or mechanistic-empirical method for road design (Ji et al. 2015).

Mechanistic-empirical methods are based on the use of empirical methods in the mechanistic solutions. Such methods include, for example, the Shell method, which was developed in 1963 used to design susceptible surfaces (Piłat and Radziszewski 2004). In the presented method we are dealing with the use of soil resistance indicators as well as the modulus of elasticity and the Poisson's coefficient.

The Empirical Method is based on the use of the CBR method, which was created in the United States between 1928 and 1929. In 1940 it was recognized by the United States Army Corps of Engineers as the primary design method for susceptible roads, airports (Craig 2004). Empirical methods include the Wyoming Method, the British Method, the PJ-IBD. Considering the presence of the resilient modulus, in the AASTHO method it is desited to determine the relationship between resilient modulus value obtained from triaxial compression tests and CBR tests, a commonly used type of research in the road laboratories. This would allow companies to designate a resilient modulus without incurring additional costs. What would translate into the dissemination of design methods using $M_{r}$ or would lead to the emergence of new design methods. 


\section{METHODS}

Determination of the resilient modulus using a triaxial compression apparatus was performed by the CU and CD method. The following formula was employed to determine the resilient modulus (Sas and Głuchowski 2012)

$$
M_{r}=\frac{\sigma_{d}}{\varepsilon_{a}}
$$

where:

$\sigma_{d}-$ axial deviator stress;

$\varepsilon_{a}$ - resilient strain.

The axial deviator stress is calculated by:

$$
\sigma_{d}=\frac{P}{A_{i}}
$$

where:

$P$ - applied force;

$A_{i}$ - cross-sectional area of the sample.

Resilient strain is calculated by the formula (Araya 2011):

$$
\varepsilon_{a}=\frac{\Delta L}{L_{i}}
$$

where:

$\Delta L$-is resilient displacement in one cycle;
$L_{i}$ - initial height of the sample.

The pattern of conducted cyclic loading is presented on Figure 1.

The CBR static test is an empirical method for assessing the soil bearing capacity characteristic (Araya 2011). The CBR testing is recommended by AASHTO (2008) and national directives WT-4 and WT-5 (2010). The cCBR test involves the use of a equipment from the CBR test, and the test itself is carried out by means of a standard CBR test and is carried out under cyclic conditions. As a result of the soil material repeating load are a plastic and elastic or resilient deformations. After few cycles, only the resilient deformation can be observed. The cCBR test procedure consists of penetrating the specimen with a plunger to a depth of $2.54 \mathrm{~mm}$ at a constant speed of $1.27 \mathrm{~mm}$ per minute. Upon reaching the desired depth of penetration, the unload phase is performed and the stress is reduced to $10 \%$ of the maximum penetration stress that occurs at a depth of $2.54 \mathrm{~mm}$ (Sas and Głuchowski 2012). The stresses expressed in $\mathrm{MPa}$ and deformations expressed in \% are determined from the cCBR test. The resilient modulus $\left(M_{r}\right)$ from cCBR test is calculated as

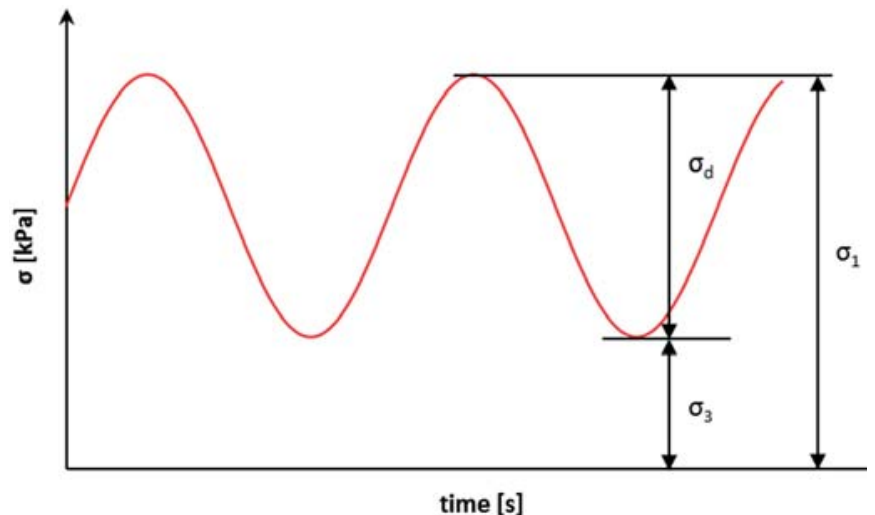

FIGURE 1. Schema of deviator stress change versus time in cyclic triaxial test conditions 
well as standard resilient modulus value in this study and is denoted as $M_{r c C B R}$. The results of above-mentioned calculations are later compared. The following formula presents a way to calculate reslient modulus from cCBR test:

$$
M_{r c C B R}=\frac{\sigma_{d c C B R}}{\varepsilon_{a}}
$$

where:

$\sigma_{d c C B R^{-}}-$axial vertical stress applied on sample $(\mathrm{kPa})$;

$\varepsilon_{a}-$ resilient cCBR strain (-).

Axial vertical stress is calculated by following formula:

$$
\sigma_{d}=\frac{P}{A_{c C B R}}
$$

where:

$P$ - applied vertical force $(\mathrm{kN})$;

$A_{C C B R}$ - area of the cCBR plunger.

Resilient cCBR strain is calculated as quotient of resilient deformation during one cycle to initial sample height.

\section{RESILIENT MODULUS MODEL}

To determine the correlation characteristics between trend lines representing the results obtained in the triaxial compression test in cyclic conditions and cCBR test. The $M_{r}-\theta$ model is used, which is a non-linear model, depending on the stress. Figure 2 presents $M_{r}-\theta$ model in a double logarithmic scale.

In this type of model, resilient modulus is calculated by following formula:

$$
M_{r}=k_{1}\left(\frac{\theta}{\sigma_{0}}\right)^{k_{2}}
$$

where:

$M_{r} \quad-$ resilient modulus (MPa);

$k_{1}, k_{2}-$ material parameters (-);

$\theta-$ total stress $(\mathrm{kPa}), \theta=\sigma_{1}+\sigma_{2}+\sigma_{3}$,

$\sigma_{0}-$ reference stress $(\mathrm{kPa}), \sigma_{0}=1$.

The $M_{r}-\theta$ model is a commonly used model with several special features. Stress is expressed by total stress, which means that all combinations of major stresses affect the resilient modulus equally (Hicks and Monismith 1971, Uzan 1985). In addition, studies have shown that the Poisson's ratio varies with the applied stress, which is not accounted for by the model (Kolisoja 1997, Van Niekerk et al. 2002). However, the selected model is sufficiently accurate to determine the correlation coefficient in this study.

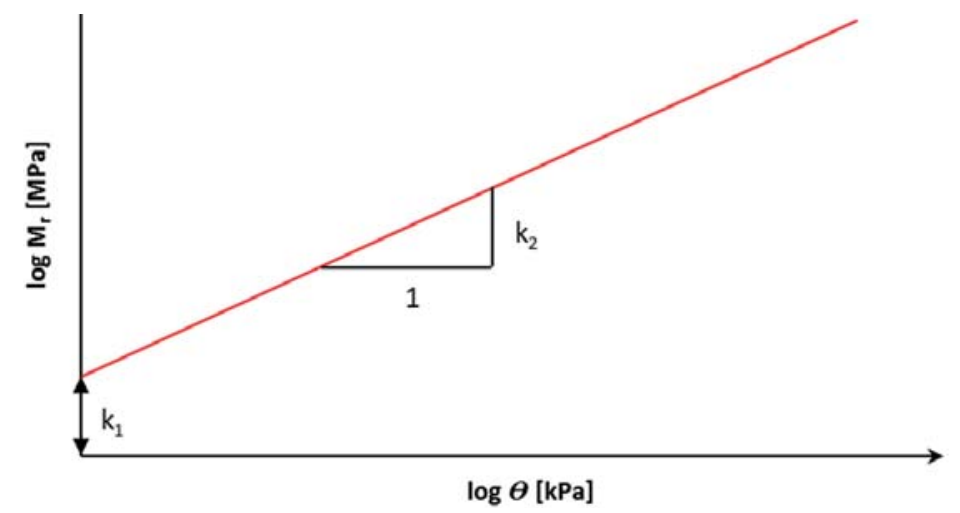

FIGURE 2. Schema of deviator stress change versus time in cyclic triaxial test conditions 


\section{MATERIAL}

The soil used for tests in this study was taken from $0.7 \mathrm{~m}$ deep earthwork on road construction site. In order to determine physical properties, series of cyclic loading tests were conducted (4 cyclic triaxial tests, 9 unconfined uniaxial cyclic loading tests and 3 cyclic CBR test).

The sieve and aerometric the analysis lead to the classification of material as sandy silty clay (sasiCl), in accordance with PN-EN ISO 14688-2:2006. Figure 3 presents test results. Studies have been performed under existing Polish standards PN-S-02205:1988 and PN-88/B-04481.

During the CBR tests samples were prepared in accordance with the existing Polish standards procedures. Compaction of specimens for CBR test was performed to obtain $0.59 \mathrm{~J} / \mathrm{cm}^{3}$ compaction energy with respect to optimum moisture content.

Representative specimens were prepared from large samples of soil material, with respect to Proctor's method, preliminary tests lead to estimate optimal moisture content equal $11.8 \%$ at dry density equal $2.01 \mathrm{~g} / \mathrm{cm}^{3}$. The test was conducted by the compaction in the Proctor's mold, whose volume equaled $2.2 \mathrm{dm}^{3}$ with the use of standard energy of compaction, equaled $0.59 \mathrm{~J} / \mathrm{cm}^{3}$. The tests were conducted in respect to $\mathrm{PN}$ -S-02205:1988.

\section{RESULTS}

Series of cyclic tests were conducted in order to characterize deformation behavior of tested material. The cyclic triaxial test results are presented on Figure 4. The samples were compacted in triaxial mould (7 cm diameter, $14 \mathrm{~cm}$ hight) with respect to Proctor's method in optimum moisture content. After compaction, sample was placed in triaxial chamber and consolidated to $\sigma_{3}{ }_{3}$ equal to 20 and $40 \mathrm{kPa}$. The samples in this study were studied in undrained condition. The purpose of such treatment, was to maintain similar conditions of the test between triaxial, uniaxial and cCBR tests. The frequency of the cyclic triaxial test was equal to $0.00667 \mathrm{~Hz}(150 \mathrm{~s}$ for one cycle). The resilient modulus value was calculated for tests performed under two deviator stress $\left(\sigma_{d}\right)$ equal to 26.0 and

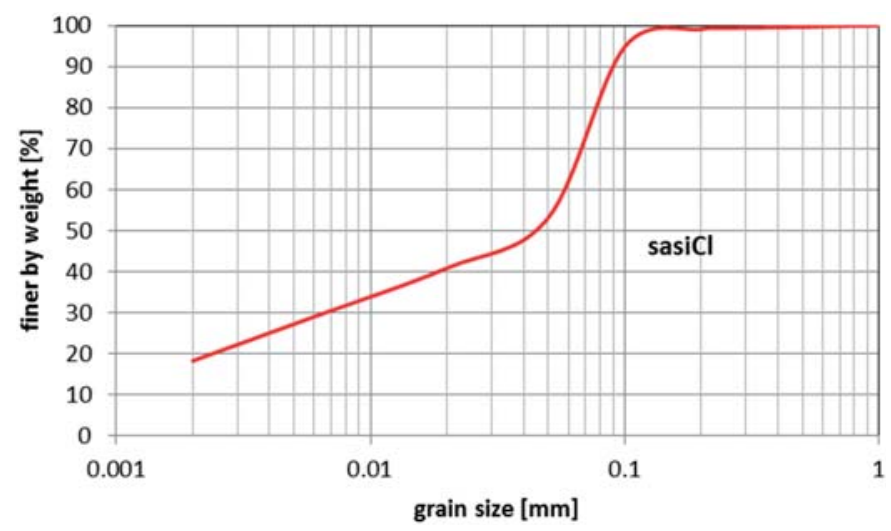

FIGURE 3. Particle size distribution in tested soil 
$45.0 \mathrm{kPa}$. The descriptive statistics for cyclic triaxial test results are as follows: average value $M_{\text {r avg }}$ equal to $42.75 \mathrm{MPa}$, standard deviation $(\sigma)$ equal to $5.74 \mathrm{kPa}$ for $\sigma_{d}$ equal to $26.0 \mathrm{kPa}$ and $\sigma_{3}$ equal to $20 \mathrm{kPa}$ and $M_{\text {r avg }}$ equal to $49.75 \mathrm{MPa}$, $\sigma$ equal to $9.13 \mathrm{kPa}$ for $\sigma_{d}$ equal to $26.0 \mathrm{kPa}$ and $\sigma_{3}$ equal to $40 \mathrm{kPa}$. The descriptive statistic was calculated for all 100 cycles in one test series.

The uniaxial repeating load tests were performed under constant stress conditions (Fig. 5). The frequency of loading was equal to $0.00667 \mathrm{~Hz}$ and the minor stress $\sigma_{3}{ }_{3}$ was equal to $0 \mathrm{kPa}$ (unconfined conditions). The unconfined cyclic tests was characterized by constant stress cyclic loading where the $\sigma_{d}$ was equal to $50.5,73.8,102.9$ and $142.9 \mathrm{kPa}$. The descriptive statistics for this test results are as follows, the average resilient modulus value $M_{r \text { avg }}$ was equal to $323.4,457.0$, 417.9 and $365.7 \mathrm{MPa}$, respectively. The standard deviation $\sigma$ equals $59.3 \mathrm{kPa}$ for $\sigma_{d}$ equal to $50.5 \mathrm{kPa}, 60.1 \mathrm{kPa}$ for $\sigma_{d}$ equal to $73.8 \mathrm{kPa}, 76.7 \mathrm{kPa}$ for $\sigma_{d}$ equal to $102.9 \mathrm{kPa}$ and $49.1 \mathrm{kPa}$ for $\sigma_{d}$ equal to $142.9 \mathrm{kPa}$.
When cyclic triaxial test are compared to unconfined cyclic tests, it is easy to see that the resilient modulus value is around ten times greater in case of tests in unconfined conditions. Nevertheless, standard deviation $(\sigma)$ shows that resilient modulus tends to be less various in case of unconfined tests.

Both tests resilient modulus characteristics shows the same evolution phenomena. At the beginning of the test, the $M_{r}$ value rapidly decreases to constant value after 10 to 20 cycles. This phenomena is caused by plastic strain development. After above-mentioned first stage, the plastic strains are much smaller and the sample behavior can be recognized as a shakedown.

In case of cCBR tests, the results are presented on Figure 6. The cCBR tests were performed with the same manner as two previous studies. The frequency equaled to $0.00667 \mathrm{~Hz}$ and 50 cycles were performed. The tests was conducted on sandy silty clay compacted in CBR mould with respect to Proctor's method in optimum moisture content as well as previous tests. The three tests

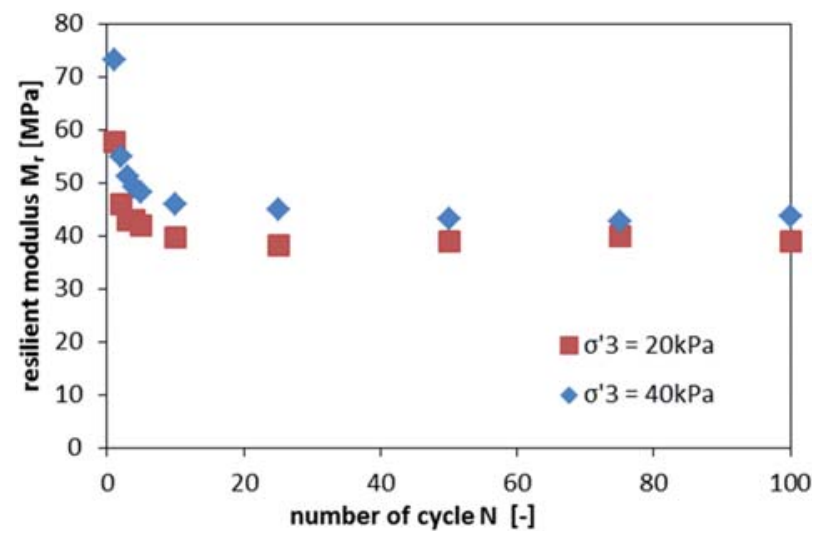

FIGURE 4. Resilient modulus value from cyclic triaxial tests for $\sigma_{d}$ equal to $26.0 \mathrm{kPa}$ and $\sigma_{3}{ }_{3}$ equal to 20 and $40 \mathrm{kPa}$ 


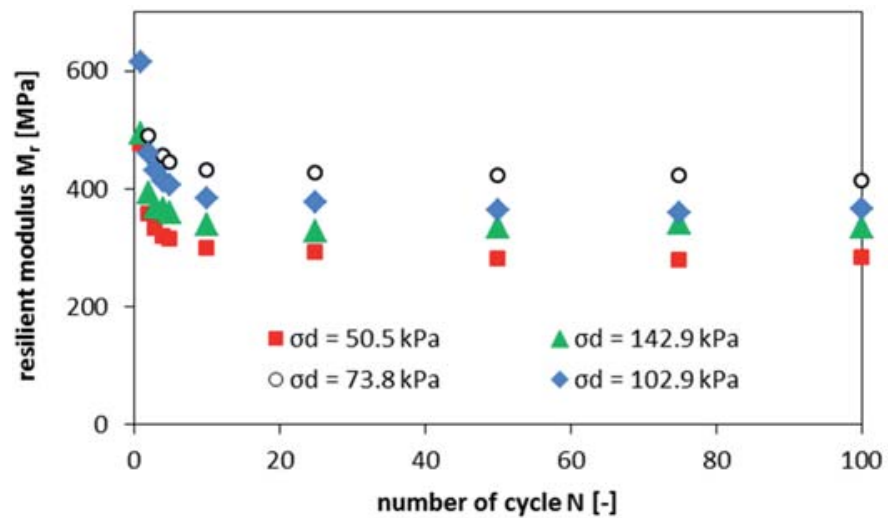

FIGURE 5. Resilient modulus value from unconfined uniaxial cyclic loading tests for various values of deviator stress $\left(\sigma_{d}\right)$

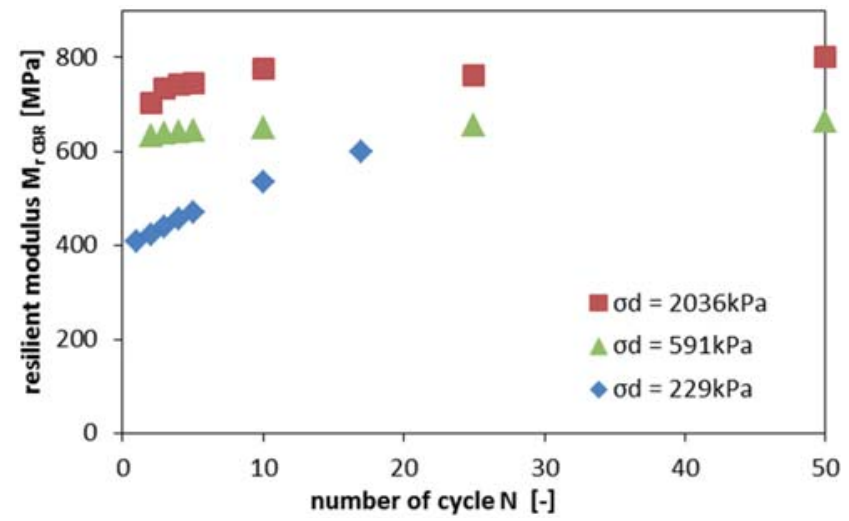

FIGURE 6. Resilient modulus value from cCBR tests for various values of axial stress $\left(\sigma_{d}\right)$

were performed. The stress applied on sample was equal to 100,30 and $11 \%$ of the stress obtained on $2.54 \mathrm{~mm}$ plunger penetration during standard CBR test (the CBR value therefore was equal to $30 \%)$. The axial stress $\left(\sigma_{d}\right)$ was equal to $2,036 \mathrm{kPa}(100 \%$ of the stress value at $2.54 \mathrm{~mm}$ depth), $591 \mathrm{kPa}(30 \%$ of the stress) and $229 \mathrm{kPa}(11 \%$ of the stress). The cCBR resilient modulus $\left(M_{r C B R}\right)$ was equal to $756.5,690.3$ and $254.6 \mathrm{MPa}$, respectively. Test in axial stress equal to $229 \mathrm{MPa}$ conditions was terminated in $17^{\text {th }}$ cycle due to software error.
The results of conducted tests were later employed to designate the characteristics of resilient modulus. For this goal, the $M_{r}-\theta$ model was utilized. Figure 7 presents results of this calculations for all three tests. Table presents the value of resilient modulus in certain stress conditions which were used to data analysis.

The resilient modulus values presented on Figure 7 indicates two different levels of $M_{r}$ quantity. This clearly indicates that the $M_{r}$ calculated based on cyclic triaxial test and $M_{r C B R}$ calculated for $\mathrm{cCBR}$ test cannot be directly compared. Based 


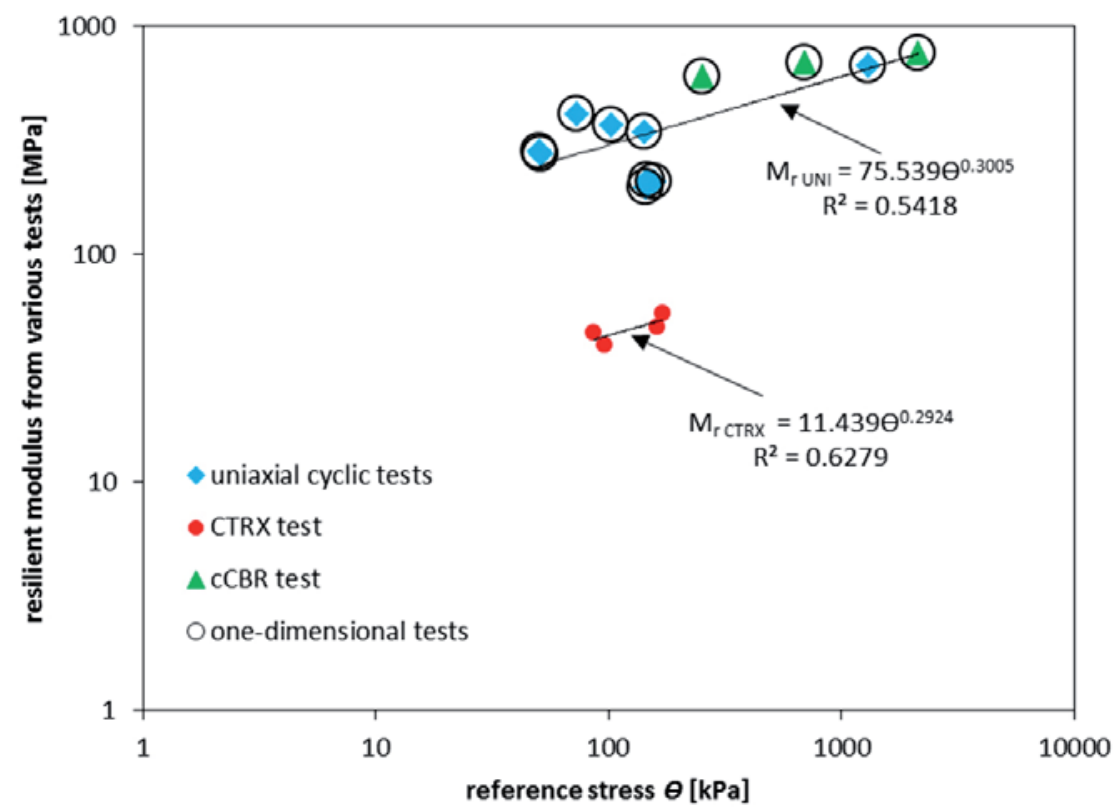

FIGURE 7. Resilient modulus value noted at 50 cycle of loading on the $M_{r}-\Theta$ model plot for three cyclic loading

on Eq. (6), the material constants $\mathrm{k}_{1}$ and $\mathrm{k}_{2}$ can be assigned for cyclic triaxial tests as well as for uniaxial unconfined cyclic tests and for cCBR test. Based on similar dependence between $M_{r}$ and $\theta$ for both uniaxial tests, the $M_{r}-\theta$ model material constants have been designated (Fig. 7).

The $\mathrm{k}_{2}$ constant for both tests is very similar which means that for cyclic triaxial and uniaxial tests the change of $M_{r}$ value with change of reference stress $(\theta)$ is the same. For the sandy silty clay in this study, the $\mathrm{k}_{2}$ is between 0.29 and 0.30 . The $\mathrm{k}_{1}$ constant denotes theoretical value of resilient modulus in "at rest" state. The $M_{r}-\theta$ model $\mathrm{k}_{1}$ value for CTRX tests is equal to $11.439\left(\mathrm{k}_{1} \mathrm{CTRX}\right)$ and for uniaxial tests is equal to 75.539 $\left(\mathrm{k}_{1}\right.$ UNI $)$.

Based on this, the conclusion can be drown, to characterize $M_{r}$ value during
TABLE. Resilient modulus value for three kinds of cyclic loading tests

\begin{tabular}{|c|c|c|c|}
\hline Test & $\sigma_{3}$ & $\sigma_{d}$ & $M_{\text {ravg }}$ \\
\hline \multirow{4}{*}{ CTRX } & \multirow{2}{*}{20} & 26 & 42.75 \\
\hline & & 45 & 48.22 \\
\hline & \multirow{2}{*}{40} & 26 & 49.75 \\
\hline & & 45 & 50.11 \\
\hline \multirow{8}{*}{ UCT } & \multirow{8}{*}{0} & 50.5 & 323.4 \\
\hline & & 52.3 & 326.3 \\
\hline & & 73.8 & 457 \\
\hline & & 89.4 & 438.5 \\
\hline & & 102.9 & 417.9 \\
\hline & & 139.8 & 361.2 \\
\hline & & 142.9 & 365.7 \\
\hline & & 145.5 & 363.4 \\
\hline \multirow{3}{*}{$\mathrm{cCBR}$} & \multirow{3}{*}{0} & 229 & 254.6 \\
\hline & & 591 & 690.3 \\
\hline & & 2036 & 756.5 \\
\hline
\end{tabular}


cCBR based only on $M_{r C B R}$ value, we can simply have to divide $M_{r}$ CBR by 6.61 $\left(\mathrm{k}_{1 \text { UNI }} / \mathrm{k}_{1 \text { CTRX }}\right)$. This can be rewritten to following formula:

$$
M_{r}=\frac{M_{r C B R}}{6,61}
$$

where calculated $M_{r}$ value applies to certain stress triaxial conditions.

The stress conditions can be characterized by following formula:

$$
\sigma_{d C B R}=\theta_{C T R X}
$$

if for example $\sigma_{d C B R}$ for cCBR test from this study was equal to $229 \mathrm{kPa}$, the correspond $M_{r C B R}$ equals to $599 \mathrm{MPa}$. Based on Eq. (7), the $M_{r}$ equals $90.6 \mathrm{MPa}$ for $\theta_{C T R X}$ equal to $229 \mathrm{kPa}$. If for example one would like to find the deviator stress value $\left(\sigma_{d}\right)$ for such reference stress, the effective minor stress $\left(\sigma_{3}^{\prime}\right)$ must be known. For $\sigma_{3}$ equal to $25 \mathrm{kPa}$, based on following relationship $\theta=\sigma_{1}+\sigma_{2}+\sigma_{3}$, the $\sigma_{d}$ must be equal to $179 \mathrm{kPa}$ and for $\sigma_{3}{ }_{3}$ equal to $45 \mathrm{kPa}$ $\sigma_{d}$ must be equal to $139 \mathrm{kPa}$.

\section{CONCLUSIONS}

The geotechnical design of constructions under cyclic loading need to also take into account the resilient modulus value. In this study, cohesive material namely sandy silty clay was studied in order to find correlation between cyclic triacial tests and uniaxial tests as unconfined uniaxial cyclic tests and cyclic CBR test. The test results lead to the following conclusions:

1. The cyclic triaxial tests cannot be directly compared with uniaxial tests as
cCBR and uniaxial unconfined cyclic tests. The resilient modulus obtained from cyclic triaxial tests is lower than $M_{r}$ from uniaxial tests.

2. The application of the $M_{r}-\theta$ model show the similarity between uniaxial unconfined cyclic tests and cCBR tests. The constants $\mathrm{k}_{1}$ and $\mathrm{k}_{2}$ for sandy silty clay for both tests were the same.

3. The formula for resilient modulus value based on $M_{r C B R}$ from cCBR test was proposed. The formula is valid for studied in this article soil material. Nevertheless, if the $\mathrm{k}_{2}$ coefficient from cCBR test and CTRX test for another soil materials would present the same behavior, the proposed formula may be become a general material model.

\section{REFERENCES}

AASHTO 1986: Guide for Design of Pavement Structures, Washington, D.C.

AASHTO 1993: Guide for Design of Pavement Structures, Washington, D.C.

AASHTO 2008: Mechanistic-Empirical Pavement Design Guide, Interim Edition: A Manual of Practice, PE Exam Edition, Washington, D.C.

AASHTO T-294-921:1994. Standard Method of Test for Resilient Modulus of Unbound Granular Base/Subbase Materials and Subgrade Soils - SHRP Protocol P46, Washington D.C.

ARAYA A.A. 2011: Integrating traditional characterization techniques in mechanistic pavement design approaches. In: S.L. Al-qadi S. Murrel (Eds.). T\&di congress 2011 Integrated Transportation And Development For A Better Tomorrow. Reston, USA, 596-606.

CRAIG R.F. 2004: Craig's soil mechanics. CRC Press. 
HICKS R.G., MONISMITH C.L. 1971: Factors influencing the resilient properties of granular materials. Highway Res. Rec. 345, 15-31.

HVEEM F.N. 1955: Pavement deflections and fatigue failures. Highway Res. Board Bull. 114.

JASTRZĘBSKA M., KALINOWSKA-PASIEKA M. 2015: Wybrane metody badawcze we współczesnym laboratorium geotechnicznym: od podłoża do parametrów gruntowych. Wydawnictwo Politechniki Sląskiej, Gliwice [in Polish].

JI R., NANTUNG T., SIDDIKI N., LIAO T., KIM D. 2015: Field and Laboratory Determination of Subgrade Resilient Modulus and its Application in Pavement Design. J. Test. Eval. 43 (5), 1109-1119.

KOLISOJA P. 1997: Resilient deformation characteristics of granular materials. Tampere University of Technology. PhD dissertation, Tampere, Finland.

PERALTA P., ACHMUS M. 2010: An experimental investigation of piles in sand subjected to lateral cyclic loads. 7th International Conference on Physical Modeling in Geotechnics, Zurich, Switzerland.

PIŁAT J., RADZISZEWSKI P. 2004: Nawierzchnie asfaltowe. Wydawnictwa Komunikacji i Łączności, Warszawa [in Polish].

PN-88/B-04481. Grunty budowlane. Badania próbek gruntów [in Polish].

PN-EN 13286-7:2004. Mieszanki niezwiązane i związane spoiwem hydraulicznym - Część 7: Próba cyklicznego obciążania trójosiowego mieszanek niezwiązanych [in Polish].

PN-EN ISO 14688-2:2006. Badania geotechniczne. Oznaczanie i klasyfikowanie gruntów. Część 2: Zasady klasyfikowania [in Polish].

PN-S-02205:1988. Drogi samochodowe. Roboty ziemne. Wymagania i badania. [in Polish].

SAS W., GŁUCHOWSKI A. 2012: Metodyka wyznaczania modułów sprężystości (E i Mr) na podstawie badania CBR pod obciążeniem cyklicznym. PN IKS 57, 171-181.
SAS W., GŁUCHOWSKI A., GABRYŚ K., SZYMAŃSKI A. 2015: Application of cyclic CBR test for the estimation of resilient modulus in the pavement construction. XVI ECSMGE Geotechnical Engineering for Infrastructure and Development, Edinburgh, 13-17 September 2015 Edinburgh, Scotland, 7, 3747-3752.

SCHWARTZ C.W., CARVALHO R.L. 2007: Implementation of the NCHRP 1-37A design guide. Final Report 2, 77.

SHAJARATI A., SØRENSEN K.W., NIELSEN S.K., IBSEN L.B. 2012: Behaviour of Cohesionless Soils During Cyclic Loading. Aalborg: Department of Civil Engineering, Aalborg University (DCE Technical Memorandum No 14).

SWEERE G.T.H. 1990: Unbound granular bases for roads. Doctoral dissertation, Technische Universitiet Delft, Netherland.

UZAN J. 1985: Characterization of granular material. Trans. Res. Rec. 1022 (1), 52-59.

Van NIEKERK A.A., MOLENAAR A.A.A., HOUBEN L.J.M. 2002: Effect of material quality and compaction on the mechanical behavior of base course materials and pavement performance. In 6th International Conference Bearing Capacity of Roads, Railways and Airfields, 1071-1081.

WT-4 2010: Mixture of unbound material for national roads. IBDiM. Appendix 3 to the Ordinance No. 102 of the General Directorate for National Roads and Motorways of 19 November 2010. Warsaw. [in Polish].

WT-5. 2010: Mixture of bound Hydraulic binder for national roads. IBDiM, Appendix 4 to the Ordinance No 102 of the General Directorate for National Roads and Motorways of 19 November 2010, Warsaw [in Polish].

Streszczenie: Studia nad wartościa cyklicznego modulu sprężystości z badań cyklicznego obciażania dla gruntu spoistego. W tym artykule przedstawiono metodę referencyjną dla określania cyklicznego modułu sprężystości $\left(M_{r}\right)$ w postaci metody cyklicznego CBR, a także wyko- 
nano porównanie wyników badań z wynikami trójosiowego cyklicznego ściskania i jednoosiowego cyklicznego ściskania. Główną ideą przeprowadzonych eksperymentów jest ustalenie zależności między badaniami cyklicznego obciążenia w testowaniu podłoża gruntowego i materiałów drogowych. W artykule przedstawiono wyniki badań nad gruntem spoistym, gliną piaszczystą, powszechnie występującym gruntem w Polsce. Przedstawiono wyniki cyklicznego badania trójosiowego ściskania $\mathrm{w}$ celu porównania ich z wynikami testu cyklicznego CBR (cCBR) za pomocą modelu $M_{r}-\Theta$. Przedstawiono empiryczną korelację między czynnikami uzyskanymi $\mathrm{w}$ teście trójosiowym. Przedstawiona korelacja między wynikami badań z badania cCBR i cyklicznego trójosiowego ściskania pozwala na wykorzystanie aparatu i procedury wykonywania badania CBR w określaniu wartości cyklicznego modułu sprężystości $\left(M_{r}\right)$. Metoda cCBR w porównaniu do badań cyklicznego trójosiowego ściskania pozwala na szybsze i tańsze testowanie właściwości gruntów przy obciążeniu cyklicznym. W niniejszym artykule zbadano również zachowanie się cyklicznego modułu sprężystości.

MS received June 2017

\section{Authors' addresses:}

Wojciech Sas, Andrzej Głuchowski

Laboratorium Centrum Wody

Wydział Budownictwa i Inżynierii Środowiska

ul. Ciszewskiego 6, 02-776 Warszawa

Poland

e-mail: wojciech_sas@sggw.pl andrzej_gluchowski@sggw.pl

Maciej Mitarski

Katedra Geoinżynierii

Wydział Budownictwa i Inżynierii Środowiska SGGW

ul. Nowoursynowska 166, 02-787 Warszawa

Poland

e-mail:maciej_mitarski@sggw.pl 